\title{
"Study of The Risk Factor, The Demographic Factor And Clinical Characteristics of Difficult to Control Asthma Associated with Ntm Infection"
}

\author{
Gopal Duegeshwer ${ }^{1} \mathrm{md}$, Rajendra Saugat ${ }^{2} \mathrm{md}$, M.L Gupta ${ }^{3} \mathrm{dm}$, Nalin Joshi ${ }^{3}$ \\ Md,,Manak Gujrani ${ }^{4} \mathrm{md}$, Gunjan Soni ${ }^{4} \mathrm{md}$ \\ ${ }^{1}$ Assistant Professor, ${ }^{2}$ Associate Professor, ${ }^{3}$ Professor \\ ${ }^{4}$ professor Department of Respiratory Medicine Sardar Patel Medical College Bikaner.
}

\begin{abstract}
The relationship between infection and asthma is complex. In established asthma, common viral agents, such as rhinovirus, frequently trigger exacerbations, Non tuberculous mycobacterial infection (NTM),Mycoplasma pneumoniae or Chlamydia may account for some phenotypes of persistent asthma.Atypical mycobacteria are the biologically distinct from Mycobacterium Tuberculosis, Mycobacterium Bovis and Mycobacterium Leprae. They are also referred to as the environmental mycobacteria. Human lung disease most commonly due to MAC,M.Kansasi (25\%).Pulmonary infections are more common in immunocompromised patients and in patients with pre-existing lung disease where there are structural deformity like bronchiectasis, cystic fibrosis ,COPD, Bronchial asthma, Lung Cancer, and silicosis
\end{abstract}

Keywords: Refractory asthma, chronic airway inflammation, Non tuberculous mycobacterial (NTM),

\section{Material And Method}

Hospital based observational case control study. Patients having clinical history suggestive of bronchial asthma and fulfilling the diagnostic criteria of difficult to control asthma were included in the study. Each case was matched with two control subjects. Control subjects were chosen as the next two consecutive patient with difficult to asthma attending department of respiratory medicine with difficult to control asthma. Eligible patients after a written informed consent were subjected to a routine clinical examination, blood investigation, chest $\mathrm{x}$-ray, spirometry and contrast enhanced CT with high resolution cuts . Mycobacterial culture of 2 consecutive sputum or bronchoalveolar fluid by MGIT method, including species identification by of the genotype.

Clinical and microbiological criteria for diagnosing non tubercular mycobacterial lung diseases(both required)

Clinical

1 Pulmonary symptoms, clinical examination and infiltration, nodular or cavitary opacities on chest radiograph or a high resolution computed tomography scan that shows multifocal bronchiactesis with multiple small nodule 2 Appropriate exclusion of other diagnosis.

\section{Microbiological}

possible culture results from at least two separate expectorate sputum sample, if the result from (1) are nodiagnostic, consider repeated sputum AFB examination smear and culture or 2 Positive culture result from at least one bronchial wash or lavage or Trannsbronchial or other lung biopsy with mycobacterial histopathologic feature (granulomatous inflammation or AFB) and one or more sputum or bronchial washings that are culture positive for NTM. Expert consultation should be obtained when NTM are recovered that are either infrequently encountered or that usually represent environmental contamination. Patients who are suspected of having NTM lung disease but do not meet the diagnostic criteria should be followed until the diagnosis is firmly established or excluded.

\section{Statistical Analysis:}

For the test of normality The Kolmogorov-Smirnov test is used as ( $\mathrm{P}$ value $>0.05$ ) were observed in body mass index and $\mathrm{FEV}_{1}$ data, which showed the normal distribution. While other variable like age, age at onset of asthma, duration of asthma, inhaled corticosteroid dose (ICS), duration of ICS, FEV , FEV $_{1} / \mathrm{FVC}_{\text {were }}$ not found normally distributed. The data were analyzed in SPSS version 20.0 statistical software, Primer and MS Excel. 


\section{Results}

Table-1

Age wise distribution of the study population

\begin{tabular}{|c|c|c|c|c|c|c|}
\hline Age group(yr) & Total $(n=60)$ & \multicolumn{2}{|c|}{ Case $(n=20)$} & \multicolumn{2}{|c|}{$\begin{array}{l}\text { Control } \\
(\mathrm{n}=40)\end{array}$} & $P$ value \\
\hline & No. & No. & $\%$ & No. & $\%$ & \\
\hline$<40$ & 7 & 0 & 0 & 7 & 17.5 & \multirow{3}{*}{$\mathrm{P}=0.000 \mathrm{HS}$} \\
\hline $40-60$ & 35 & 6 & 30 & 29 & 72.5 & \\
\hline$>60$ & 18 & 14 & 70 & 4 & 10 & \\
\hline
\end{tabular}

Chi Square Test, 23.629 with 2 degree of freedom

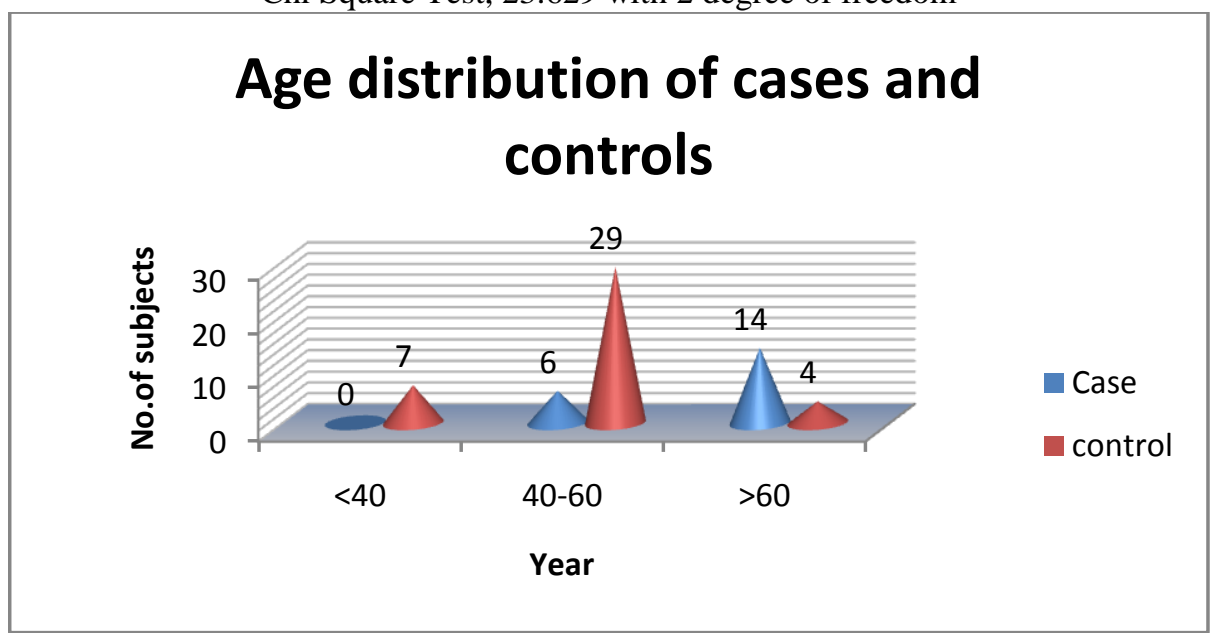

Table 1 shows age wise proportion of the subjects were more in $>60 \mathrm{yrs}(70 \%)$ of age among the cases as compared to control, while subjects were more in 40 to 60 yrs $(72.5 \%)$ of the age groups in controls. $(\mathrm{P}<0.001 \mathrm{HS})$

Table-2 Sex wise distribution

\begin{tabular}{|c|l|l|l|l|l|l|}
\hline Sex & Total $(\mathrm{n}=60)$ & \multicolumn{2}{|l|}{ Case $(\mathrm{n}=20)$} & \multicolumn{2}{l|}{ Control $(\mathrm{n}=40)$} & P Value \\
\hline & & No. & $\%$ & No. & $\%$ & \\
\hline Female & 32 & 14 & 70 & 18 & 45 & \multirow{2}{*}{$\mathrm{P}=0.120 \mathrm{NS}$} \\
\hline Male & 28 & 6 & 30 & 22 & 55 & \multirow{2}{*}{} \\
\hline
\end{tabular}

Chi Square Test 2.419 with 1 degree of freedom

\section{Sex distribution of study popoulation}

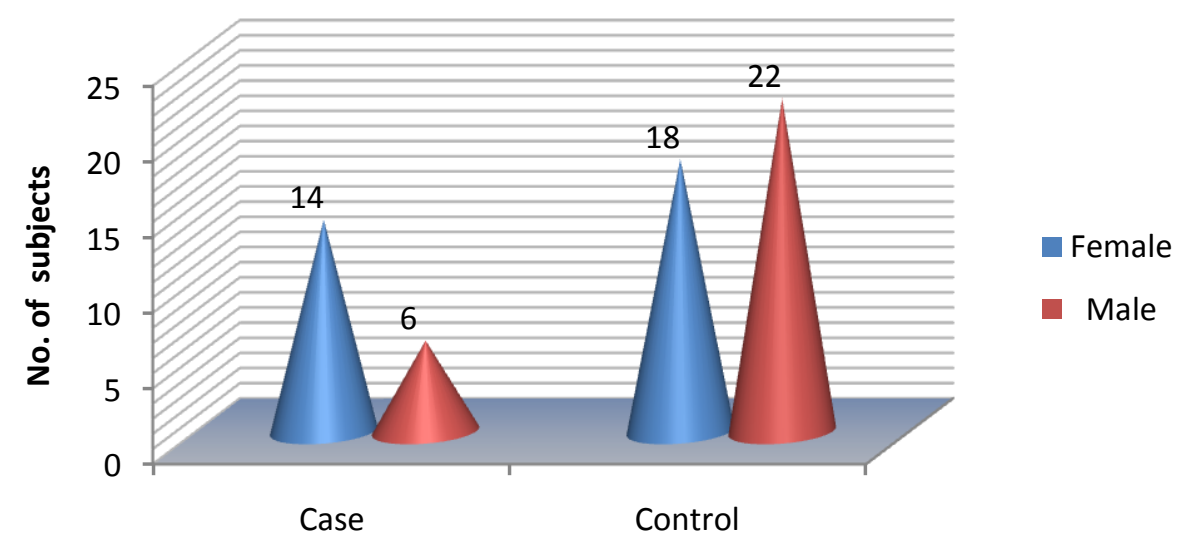

Table 2 shows sex proportion of female (70\%) was more as compare to male(30\%) among cases, while in controls $18(45 \%)$ were female and $22(55 \%)$ were male. 
Table - 3 Age of onset of asthma in study population

\begin{tabular}{|l|l|l|l|l|l|l|}
\hline \multirow{2}{*}{$\begin{array}{l}\text { Age }(\text { years }) \text { of onset } \\
\text { of Asthma }\end{array}$} & Total $(\mathrm{n}=60)$ & \multicolumn{2}{|c|}{ Case $(\mathrm{n}=20)$} & \multicolumn{2}{l|}{ Control(n=40) } & P Value \\
\cline { 2 - 7 } & & No. & $\%$ & No. & $\%$ & \\
\hline$<40$ & 37 & 8 & 40 & 29 & 72.5 & \multirow{2}{*}{$\mathrm{P}=0.031 \mathrm{~S}$} \\
\hline 40 to 60 & 23 & 12 & 60 & 11 & 27.5 & \\
\hline
\end{tabular}

Chi Square Test, 4.662 with 1 degree of freedom

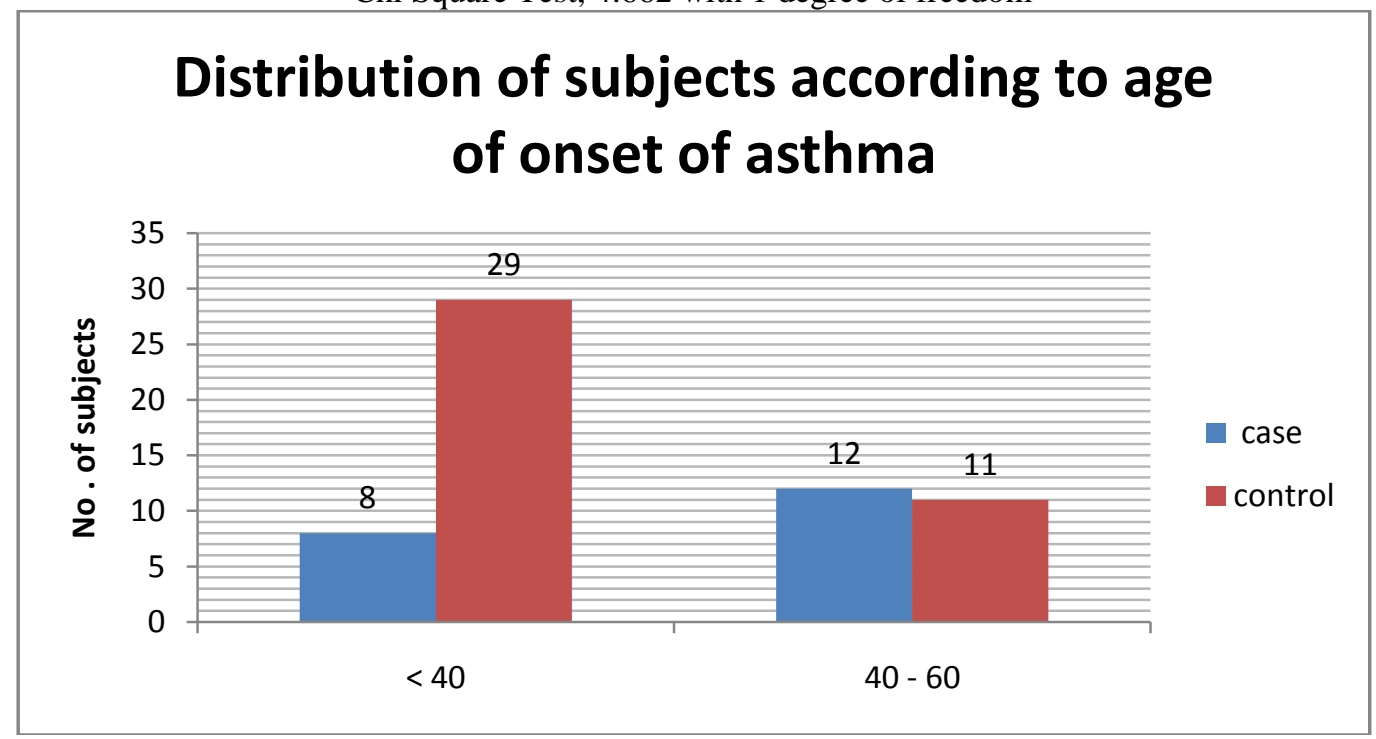

Table 3 shows age of onset of asthma in cases 40 to $60 \mathrm{yrs}(60 \%)$ of the age groups more in cases and more number of controls had onset before 40 year $(72.5 \%)$ of age and this difference was significant. $(\mathrm{P}=0.031 \mathrm{~S})$

Table-4 Duration of Asthma in study population

\begin{tabular}{|c|c|c|c|c|c|c|}
\hline \multirow{2}{*}{$\begin{array}{l}\text { Duration of } \\
\text { Asthma(years) }\end{array}$} & \multirow[t]{2}{*}{$\operatorname{Total}(n=60)$} & \multicolumn{2}{|c|}{ Case $(n=20)$} & \multicolumn{2}{|c|}{ Control $(n=40)$} & \multirow[t]{2}{*}{ P Value } \\
\hline & & No. & $\%$ & No. & $\%$ & \\
\hline$<10$ & 18 & 0 & 0 & 18 & 45 & \multirow{4}{*}{$\mathrm{P}=0.000 \mathrm{HS}$} \\
\hline 10 to 20 & 29 & 8 & 40 & 21 & 52.5 & \\
\hline 21 to 30 & 9 & 8 & 40 & 1 & 2.5 & \\
\hline$>30$ & 4 & 4 & 20 & 0 & 0 & \\
\hline
\end{tabular}

Chi Square test, 29.931 with 3 degree of freedom

\section{Duration of asthma in study population}

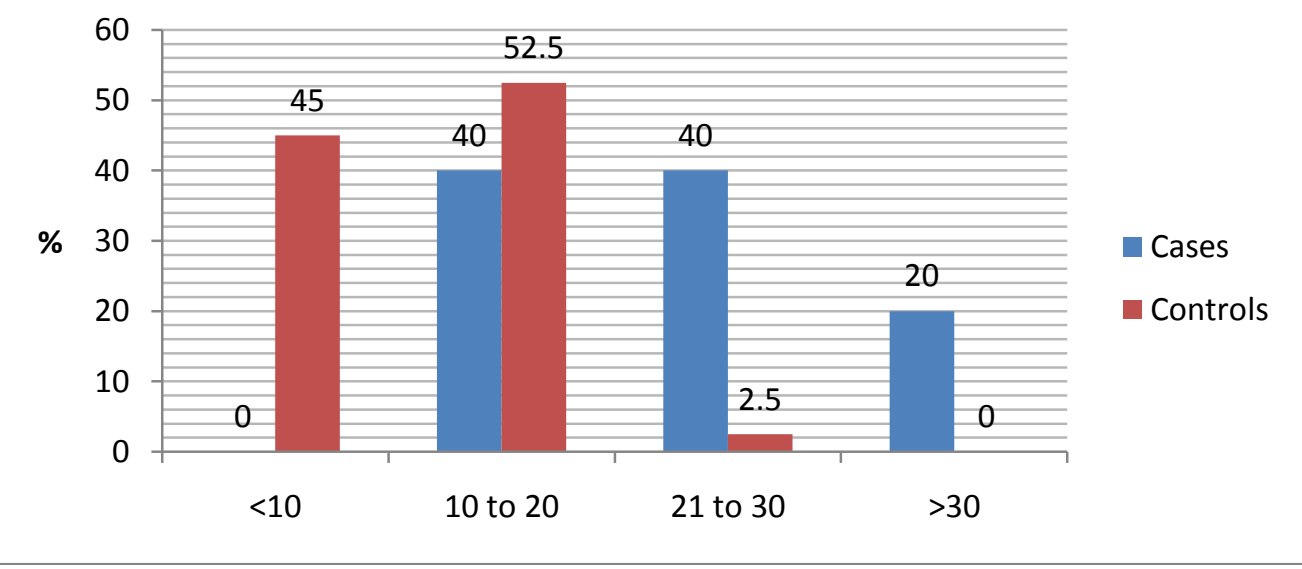

Table 4 shows duration of asthma in cases and controls. In cases $8(40 \%)$ patients each had asthma duration of $10-20$ years and $8(40 \%)$ patient 21-20 year remaining 4 patients had $>30$ years. Duration of asthma was significantly longer among the cases as compare to controls. $(\mathrm{p}<0.01)$ 
Table 5 History of Anti tubercular treatment

\begin{tabular}{|l|l|l|l|l|l|l|}
\hline \multirow{2}{*}{$\begin{array}{l}\text { History } \\
\text { ATT }\end{array}$} & $\begin{array}{l}\text { Total } \\
(\mathrm{n}=60)\end{array}$ & \multicolumn{2}{|l|}{ Case $(\mathrm{n}=20)$} & \multicolumn{2}{l|}{ Control $(\mathrm{n}=40)$} & P Value \\
\cline { 2 - 6 } & No. & No. & $\%$ & No. & $\%$ & LS \\
\hline Absent & 51 & 14 & 70 & 37 & 92.5 & \multirow{2}{*}{$\mathrm{P}=0.055$} \\
\hline Present & 9 & 6 & 30 & 3 & 7.5 & $\mathrm{P}$ \\
\hline
\end{tabular}

Chi Square Test, 3.676 with 1 degree of freedom

\section{History of antituberular treatment in study population}

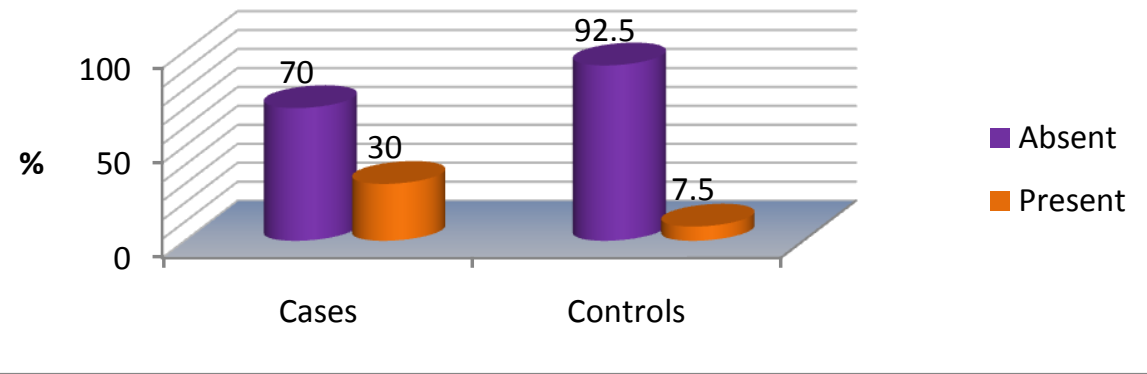

Table 5.Shows in cases 6(30\%) patient had a history of past antitubercular treatment while in control groups $3(7.5 \%)$ patient had a history antitubercular treatment. No significant difference was observed according to history of antituberular treatment among study population.

Table 6 Smoking history in study population

\begin{tabular}{|c|c|c|c|c|c|c|}
\hline \multirow[b]{2}{*}{ History of Smoking } & \multirow[t]{2}{*}{$\begin{array}{l}\text { Total } \\
(\mathrm{n}=60)\end{array}$} & \multicolumn{2}{|c|}{ Case $(n=20)$} & \multicolumn{2}{|c|}{ Control $(n=40)$} & \multirow[t]{2}{*}{ P Value } \\
\hline & & No. & $\%$ & No. & $\%$ & \\
\hline Smoker & 5 & 0 & 0 & 5 & 12.5 & \multirow{3}{*}{$P=0.165$} \\
\hline ex -smoker & 15 & 4 & 20 & 11 & 27.5 & \\
\hline Non smoker & 40 & 16 & 80 & 24 & 60 & \\
\hline
\end{tabular}

Chi Square Test, 3.600 with 2 degree of freedom

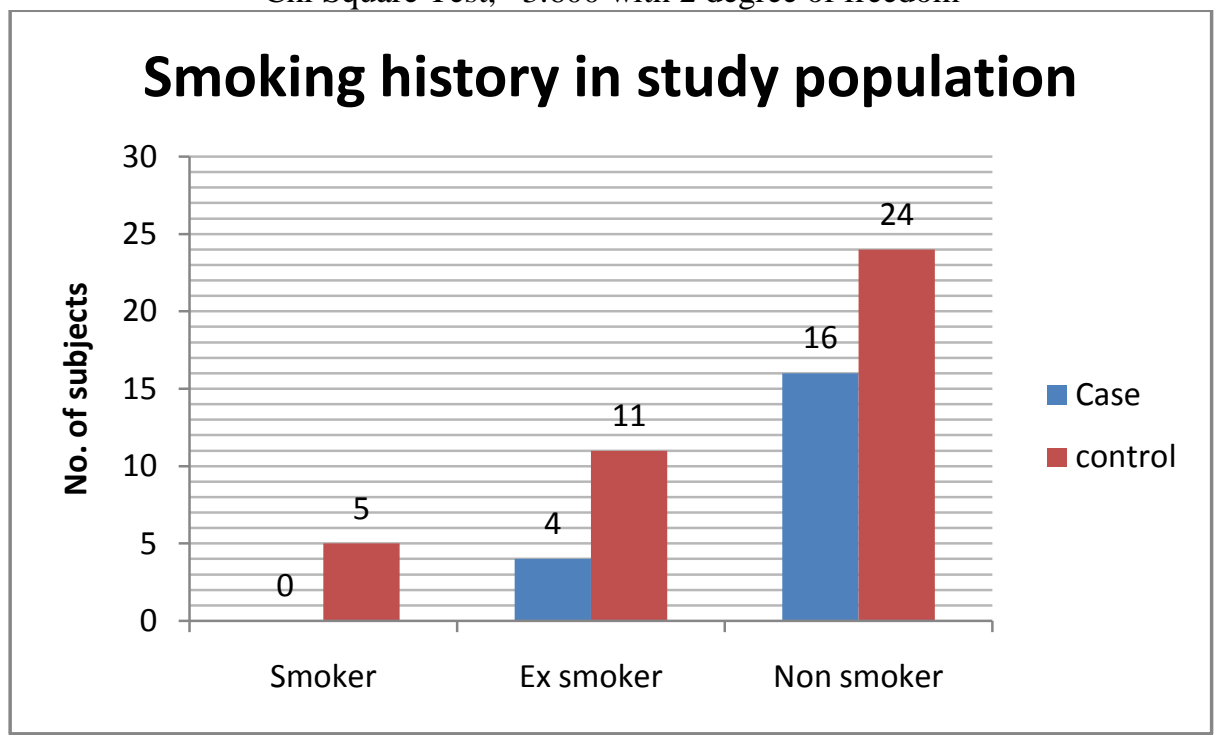


Table 6 shows in case group $4(20 \%)$ were exsmoker and 16(80\%) were non smoker, while in controls $5(12.5 \%)$ were smoker, $11(27.5 \%)$ exsmoker and 24(60\%) non smoker. No significant difference was observed in smoking status between cases and controls; most patients were lifetime nonsmokers or former smokers.

Table 7 past hospital admission in last one year in study population

\begin{tabular}{|c|c|c|c|c|c|c|}
\hline \multirow{2}{*}{$\begin{array}{l}\text { Past } \mathrm{H} / \mathrm{o} \text { hospital } \\
\text { admission }\end{array}$} & Total $(\mathrm{n}=60)$ & \multicolumn{2}{|c|}{ Case $(n=20)$} & \multicolumn{2}{|c|}{ Control $(\mathrm{n}=40)$} & Chi Square Test \\
\hline & & No. & $\%$ & No. & $\%$ & P Value \\
\hline 1 & 10 & 7 & 35 & 3 & 7.5 & \\
\hline 2 & 3 & 3 & 15 & 0 & 0 & \\
\hline Not & 47 & 10 & 50 & 37 & 92.5 & $P=0.000$ \\
\hline
\end{tabular}

Chi Square Test, 15.124 with 2 degree of freedom

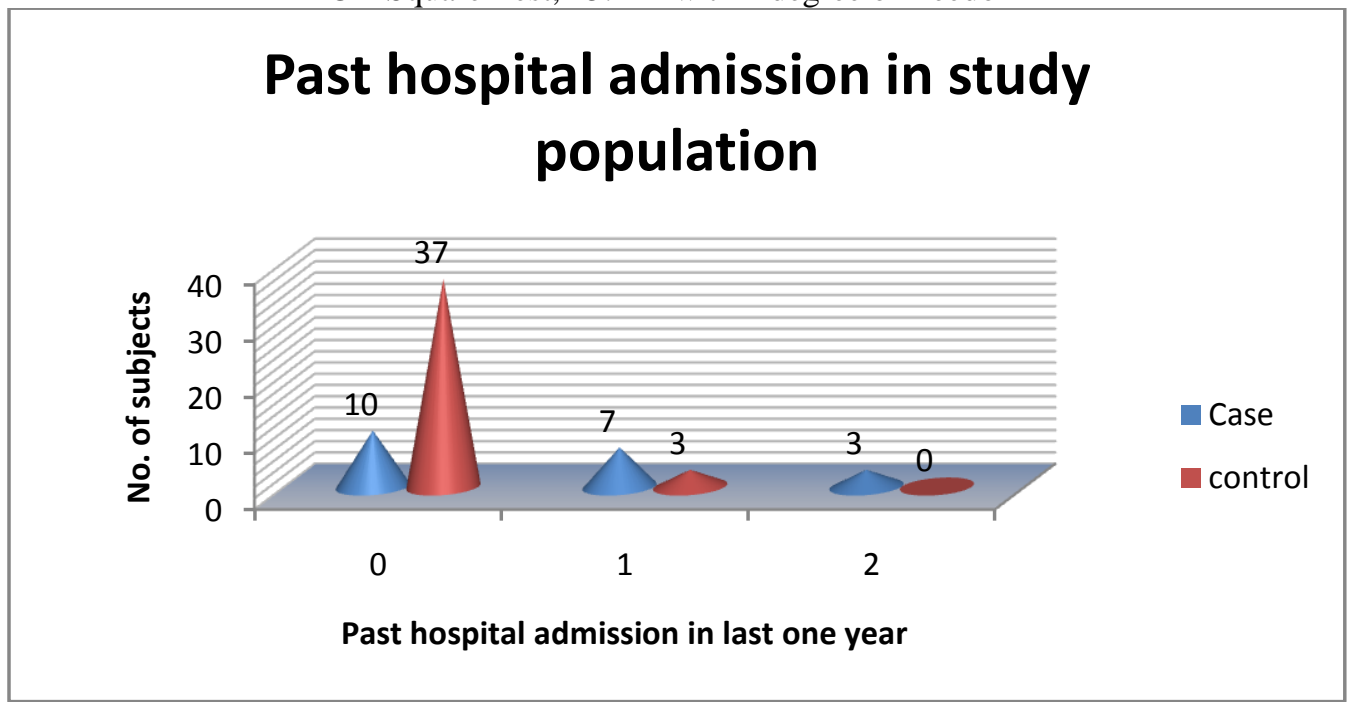

Table 7 shows past history of hospital admission in cases and controls. Among cases 7 (35\%) had once hospitalization ,3 patient (15\%) had twice and 10 patient had no past history of hospitalization, while in controls $37(92.5 \%)$ had no history of hospitalization , 3 (7.5\%) had once hospitalization. Past history of hospital admission was significantly more in cases as compared to controls ( $\mathrm{p}$ value >.001).

Table- 8 Exacerbation of asthma / year in study population

\begin{tabular}{|c|c|c|c|c|c|c|}
\hline \multirow[b]{2}{*}{ Exacerbation/per year } & \multirow[t]{2}{*}{ Total $(n=60)$} & \multicolumn{2}{|c|}{ Case (n=20) } & \multicolumn{2}{|c|}{$\begin{array}{l}\text { Control } \\
(\mathrm{n}=40)\end{array}$} & \multirow[t]{2}{*}{$\mathrm{P}$ Value } \\
\hline & & No. & $\%$ & No. & $\%$ & \\
\hline 0 & 33 & 7 & 35 & 26 & 65 & \multirow{4}{*}{$\mathrm{P}=0.017 \mathrm{~S}$} \\
\hline 1 & 18 & 6 & 30 & 12 & 30 & \\
\hline 2 & 7 & 5 & 25 & 2 & 5 & \\
\hline 3 & 2 & 2 & 10 & 0 & 0 & \\
\hline
\end{tabular}

Chi Square Test, 10.753 with 3 degree of freedom 


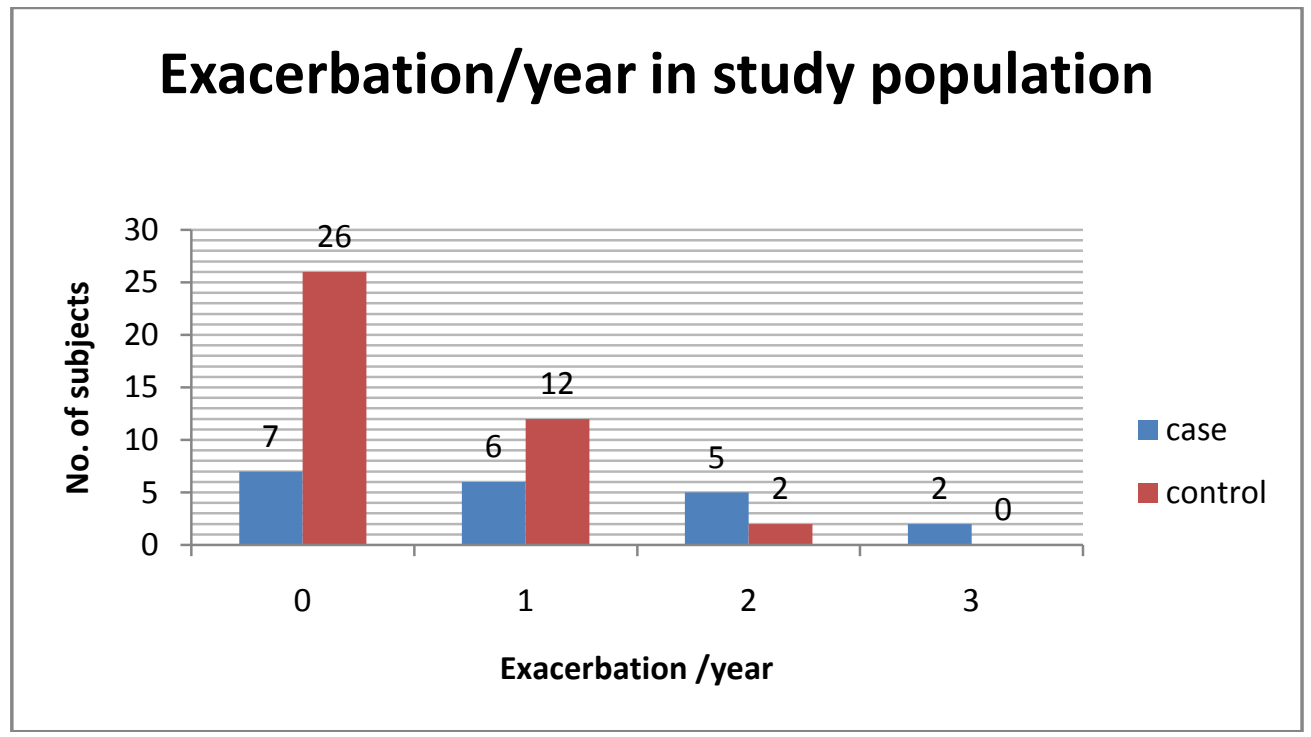

Table 8 shows number of exacerbations/year in cases and controls. Among cases 6(30\%) had 1 exacerbation/year, 5(25\%) had 2 exacerbation/ year and $2(10 \%)$ had 3 exacerbation/per year. Majority of the controls 26/40 (65\%) did not have any exacerbation and $12(30 \%)$ and $2(5 \%)$ had one and two exacerbation respectively and none of the control subjects had 3 exacerbation/year. Cases had significantly more exacerbations / year as compare to controls.

Table $\mathbf{- 9}$ History of allergy in study population

\begin{tabular}{|l|l|l|l|l|l|l|}
\hline \multirow{2}{*}{ Allergy history } & Total $(\mathrm{n}=60)$ & \multicolumn{2}{|l|}{ Case $(\mathrm{n}=20)$} & \multicolumn{2}{|l|}{ Control(n=40) } & P Value \\
\cline { 2 - 6 } & & No & $\%$ & No. & $\%$ & \\
\hline Yes & 7 & 0 & 0 & 7 & 17.5 & \multirow{2}{*}{$\mathrm{P}=0.118$} \\
\hline No & 53 & 20 & 100 & 33 & 82.5 & \\
\hline
\end{tabular}

Chi Square Test, 2.446 with 1 degree of freedom

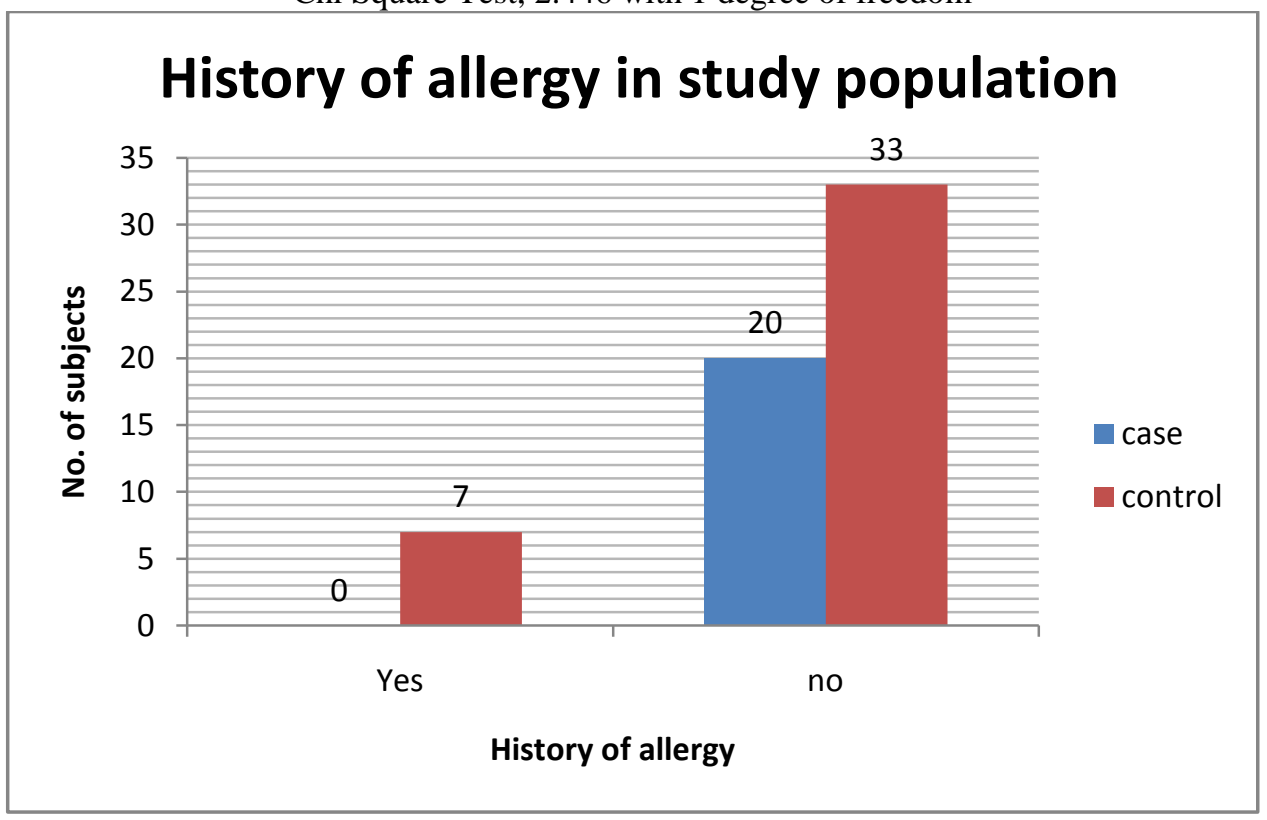

Table 9 shows history of allergy in case and control groups. No significant difference was observed according to history of allergy among cases and controls. ( $\mathrm{P}>0.05 \mathrm{NS}$ )

Table -10 Type of inhaled corticosteroid

\begin{tabular}{|l|l|l|l|l|l|l|}
\hline Inhaled corticosteroid & $\begin{array}{l}\text { Total } \\
(\mathrm{n}=60)\end{array}$ & \multicolumn{2}{|l|}{ Case $(\mathrm{n}=20)$} & \multicolumn{2}{|l|}{ Control $(\mathrm{n}=40)$} & P Value \\
\hline & & No. & $\%$ & No. & $\%$ & \\
\hline
\end{tabular}


“Study Of The Risk Factor, The Demographic Factor And Clinical Characteristi....

\begin{tabular}{|l|l|l|l|l|l|l|} 
Fluticasone & 22 & 11 & 55 & 11 & 27.5 & \\
\cline { 1 - 6 } Beclomethasone & 13 & 4 & 20 & 9 & 22.5 & \\
\cline { 1 - 3 } & 25 & 5 & 25 & 20 & 50 & $\mathrm{P}=0.091$ \\
\hline
\end{tabular}

Chi Square Test, 4.788 with 2 degree of freedom

\section{Type of inhaled corticosteroid in study population}

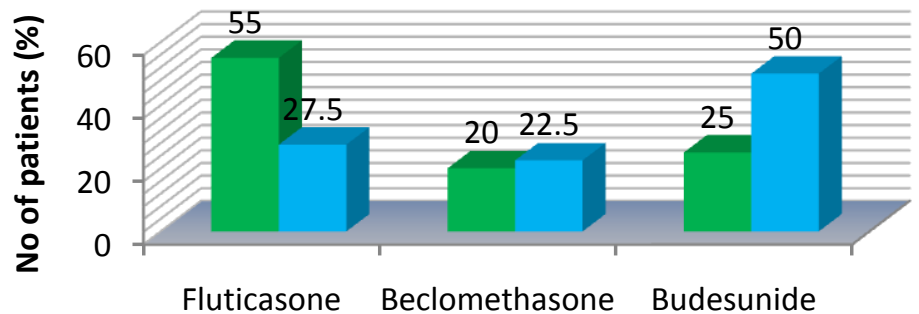

Cases

Controls

Table 10 shows type of inhaled corticosteroids used by cases and controls. In cases 11(55\%) were using fluticasone, $4(20 \%)$ were using beclomethasone, and $5(25 \%)$ were using budesonide, while in controls $11(27.5 \%)$ were using fluticasone, $9(22.5 \%)$ beclomethasone and 20(50\%) were using budesonide. No significant difference was observed according to type of inhaled corticosteroid were used among cases and controls. $(\mathrm{P}>0.05 \mathrm{NS})$

Table 11 Duration of Inhaled corticosteroid (ICS)

\begin{tabular}{|c|l|l|l|}
\hline Duration of ICS & $\mathrm{n}$ & Mean(years) & P Value \\
\cline { 1 - 3 } Case & 20 & $15.05 \pm 4.915$ & \multirow{2}{*}{0.000} \\
\cline { 1 - 3 } Control & 40 & $5.00 \pm 3.457$ & \\
\hline Total & 60 & $8.35 \pm 6.205$ & \\
\hline
\end{tabular}

\section{Duration of inhaled corticosteroids}

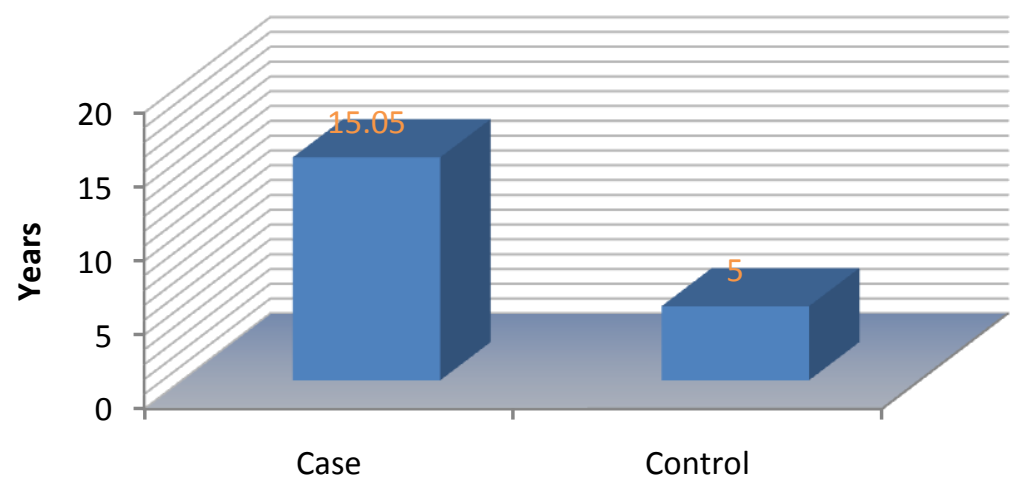

Table 11 shows duration of inhaled corticosteroid used by cases and controls. Mean duration of inhaled corticosteroid in cases was $15.05 \pm 4.915$ year and in controls $5.00 \pm 3.457$ years . Cases had a mean duration of inhaled corticosteroids significantly longer period of time, $(\mathrm{P}<0.001 \mathrm{HS})$ as compare to controls.

Table - 12 Use of Short acting beta 2 agonist (SABA)

\begin{tabular}{|l|l|l|l|l|l|l|}
\hline & $\begin{array}{l}\text { Total } \\
(\mathrm{n}=60)\end{array}$ & \multicolumn{4}{|l|}{ Case $(\mathrm{n}=20)$} & \multicolumn{2}{l|}{$\begin{array}{l}\text { Control } \\
(\mathrm{n}=40)\end{array}$} & P Value \\
\hline SABA & & No. & $\%$ & No. & $\%$ & \\
\hline Yes & 33 & 10 & 50 & 23 & 57.5 & \\
\hline No & 27 & 10 & 50 & 17 & 42.5 & $\mathrm{P}=0.783$ \\
\hline
\end{tabular}


Chi Square Test, 0.076 with 1 degree of freedom

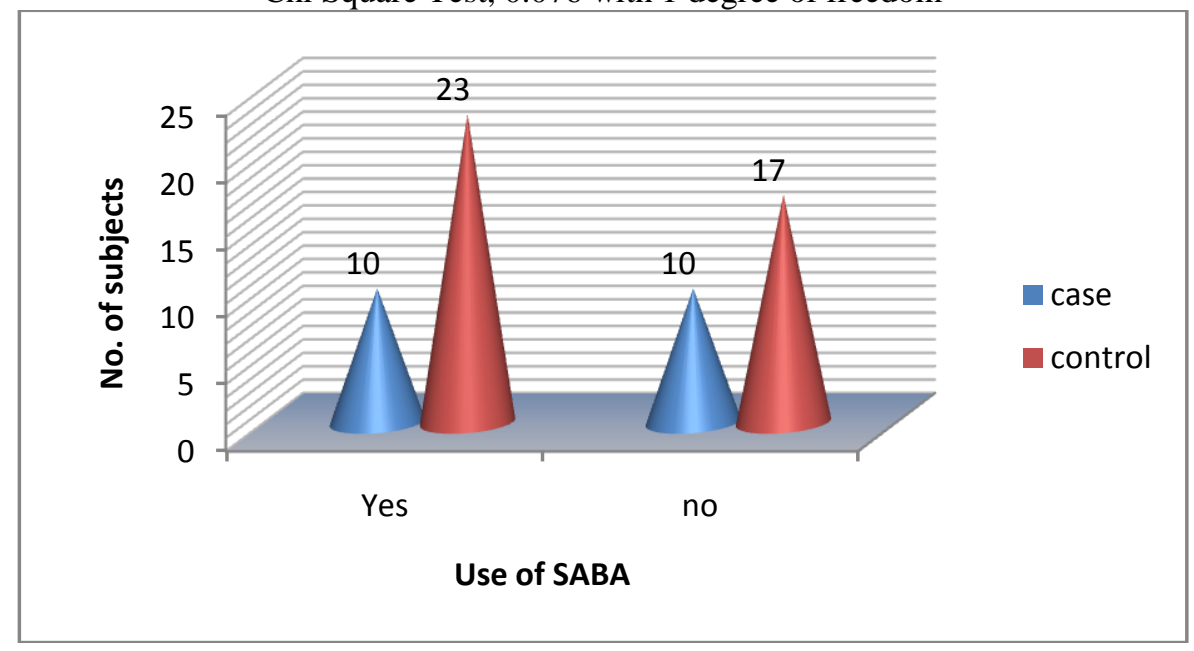

Table 12 show use of short acting beta 2 agonist in cases and controls. Among case 10(50\%) were using short acting beta 2 agonist, while in controls 23(57.5\%) were using short acting beta 2 agonist. No significant difference was observed according to use of short acting beta 2 agonist among cases and controls $(\mathrm{P}>0.05 \mathrm{NS})$

Table -13 Use of Long acting beta 2 agonist (LABA)

\begin{tabular}{|l|l|l|l|l|l|l|}
\hline & Total $(\mathrm{n}=60)$ & \multicolumn{2}{|l|}{ Case $(\mathrm{n}=20)$} & \multicolumn{2}{l|}{ Control(n=40) } & P Value \\
\hline LABA & & No. & $\%$ & No. & $\%$ & \\
\hline Formetrol & 24 & 7 & 35 & 17 & 42.5 & \multirow{2}{*}{$\mathrm{P}=0.26$} \\
\cline { 1 - 6 } Salmetrol & 19 & 8 & 40 & 11 & 27.5 & \\
\cline { 1 - 5 } not used & 17 & 5 & 25 & 12 & 30 & \\
\hline
\end{tabular}

Chi Square Test

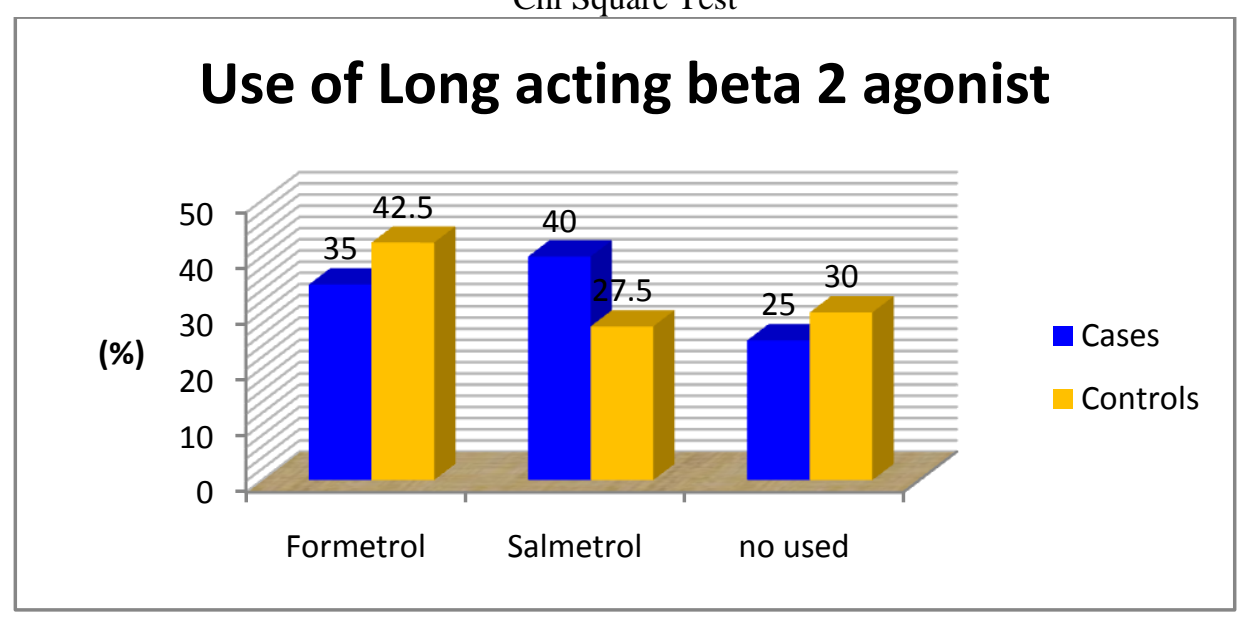

Table 13 shows use of long acting beta 2 agonist, among cases 15 (75\%) were using long acting beta 2 agonist, while in control groups 28(70\%) were using long acting beta 2 agonist .No significant difference was observed according to use of long acting beta 2 agonist .(P $>0.05 \mathrm{NS})$

Table 14 Distribution according to use of SABA plus LABA

\begin{tabular}{|l|l|l|l|l|l|}
\hline \multicolumn{5}{|c|}{ Case $(\mathrm{n}=20)$} & \multicolumn{2}{l|}{ Control $(\mathrm{n}=40)$} & P Value \\
\hline & No. & $\%$ & No. & $\%$ & \\
\cline { 1 - 5 } No & & & & & \\
\cline { 1 - 5 } Yes & 5 & 75 & 29 & 72.5 & \\
\hline
\end{tabular}

Chi Square Test, 0.011 with 1 degree of freedom 


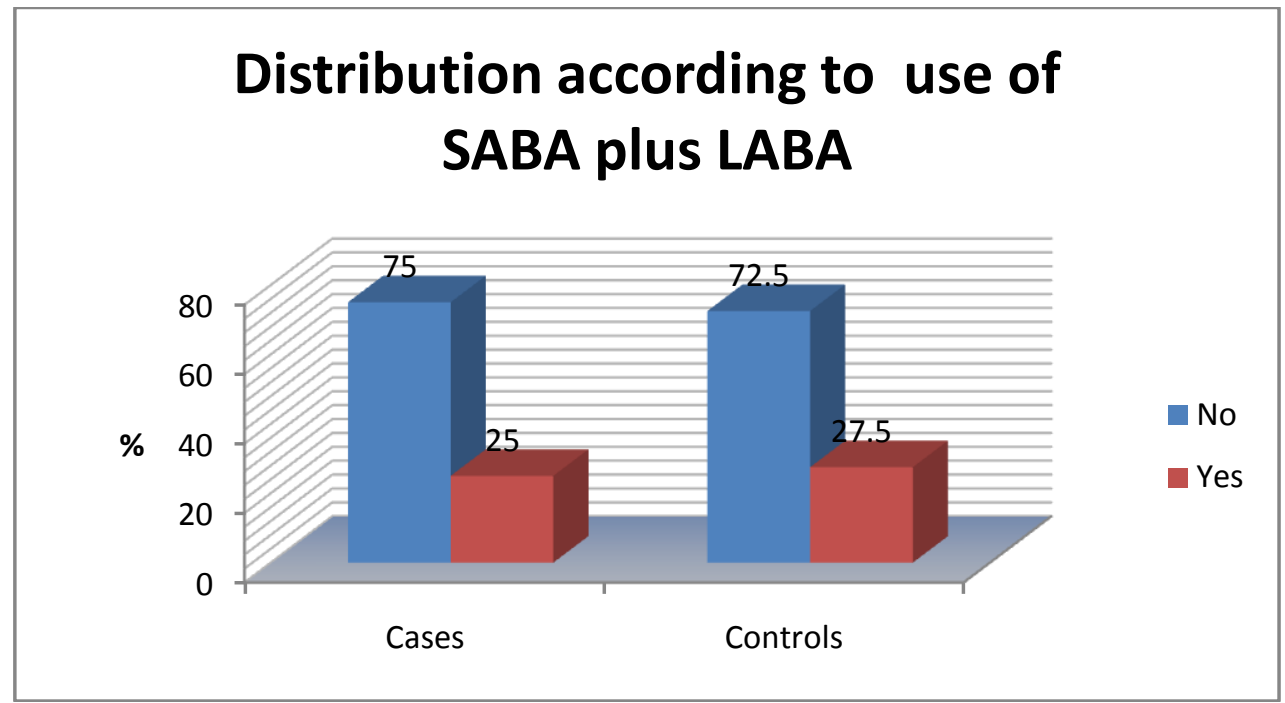

Table 14 shows distribution of subjects according to uses of short acting plus long acting beta 2 agonist. In case group $5(25 \%)$ were using both short acting plus long acting beta 2 agonist, while in control groups $11(27.5 \%)$ were using short acting plus long acting beta 2 agonist. No significant difference was observed according to use of short acting plus long acting beta 2 agonist. ( $P>0.05 \mathrm{NS}$ )

\begin{tabular}{|c|c|c|c|c|c|c|}
\hline \multirow[b]{2}{*}{ Oral steroid } & \multirow{2}{*}{ Total $(\mathrm{n}=60)$} & \multicolumn{2}{|c|}{ Case $(n=20)$} & \multicolumn{2}{|c|}{ Control(n=40) } & \multirow{2}{*}{ P Value } \\
\hline & & No. & $\%$ & No. & $\%$ & \\
\hline Yes & 15 & 12 & 30 & 3 & 7.5 & \\
\hline No & 45 & 8 & 20 & 37 & 92.5 & $\mathrm{P}=0.001$ \\
\hline
\end{tabular}

Chi Square Test, 16.900 with 1 degree of freedom

\section{Oral steroid use in study population}

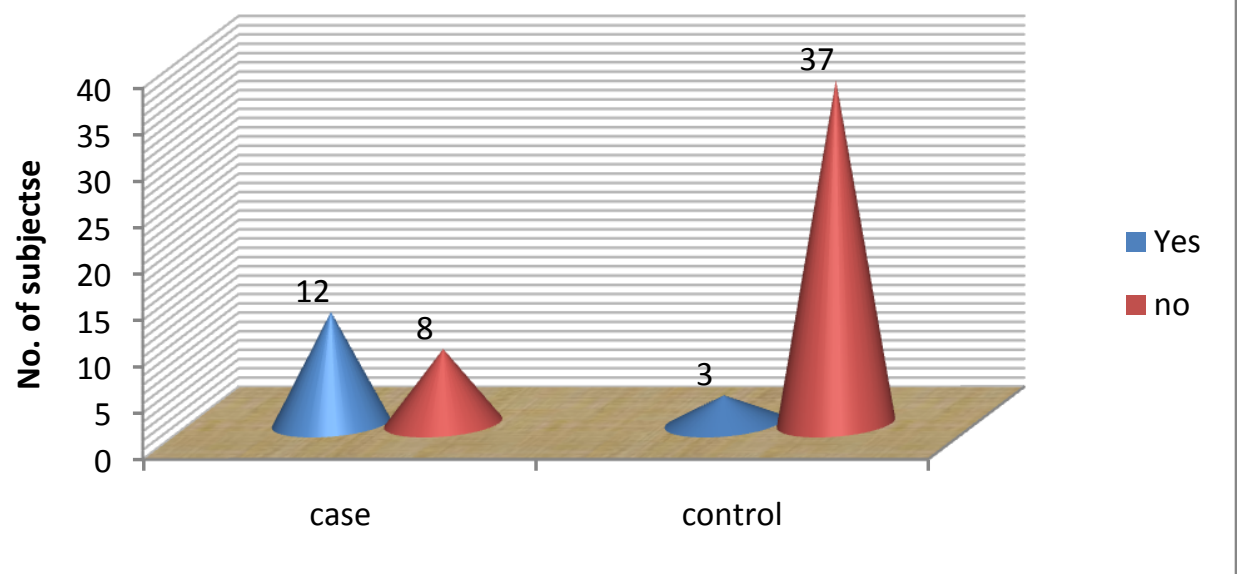

Table 15 shows oral steroid use among cases 12 (60\%) were using oral steroid while in controls 3 $(7.5 \%)$ were using oral steroids. Oral steroids were significantly more used in cases as compared to controls. $(\mathrm{P}<0.001 \mathrm{HS})$

Table 16 Distribution of symptoms in study population

\begin{tabular}{|l|l|l|l|l|l|l|}
\hline Symptoms & $\begin{array}{l}\text { Total } \\
(\mathrm{n}=60)\end{array}$ & \multicolumn{2}{|l|}{ Case $(\mathrm{n}=20)$} & \multicolumn{2}{l|}{ Control $(\mathrm{n}=40)$} & P Value \\
\hline & & No & $\%$ & No. & $\%$ & \\
\hline Fever & 17 & 14 & 70 & 3 & 7.5 & $\mathrm{P}=0.000$ \\
\hline Cough & 60 & 20 & 100 & 40 & 100 & $\mathrm{NS}$ \\
\hline Expectoration & 55 & 20 & 100 & 35 & 87.5 & $\mathrm{P}=0.248$ \\
\hline Shortness of breath & 60 & 20 & 100 & 40 & 100 & $\mathrm{NS}$ \\
\hline Loss of weight & 6 & 5 & 25 & 1 & 2.5 & $\mathrm{P}=0.022$ \\
\hline
\end{tabular}


"Study Of The Risk Factor, The Demographic Factor And Clinical Characteristi....

\begin{tabular}{|l|l|l|l|l|l|l|} 
Loss of Appetite & 7 & 5 & 25 & 2 & 5 & $\mathrm{P}=0.065$ \\
\hline
\end{tabular}

Chi Square Test

\section{Distribution of the groups according to symptoms of the diseases}

(\%)

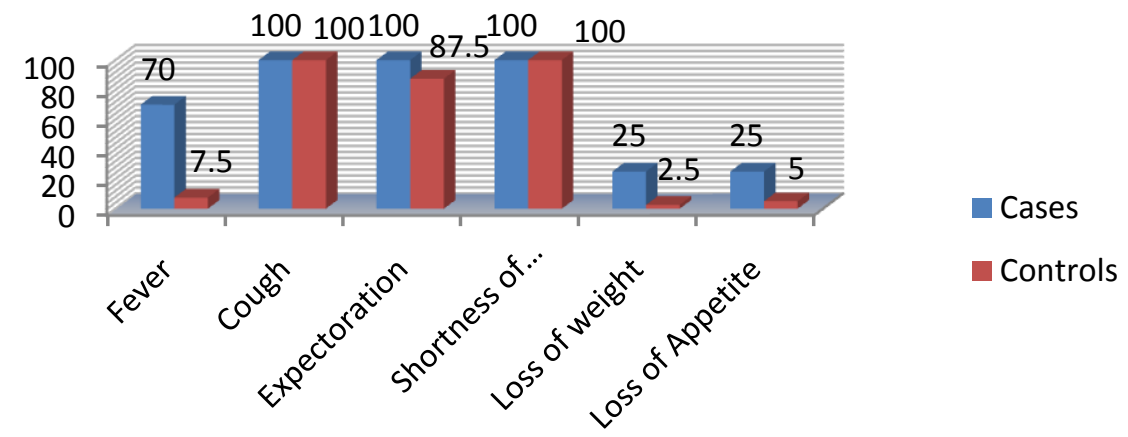

Table 16 shows symptoms in cases and controls. The most common symptomatic changes in cases were cough, expectoration and shortness of breath these were present in (100\%) cases .Significantly higher proportion of fever $(70 \%)$ and loss of weight (25\%) were observed in cases as compared to controls.

Table 17 Mean $\mathrm{FEV}_{1} / \mathrm{FVC}$ percentage in study population

\begin{tabular}{|l|l|l|l|}
\hline $\mathrm{FEV}_{1} / \mathrm{FVC} \mathrm{( \% )}$ & $\mathrm{n}$ & Mean & P Value LS \\
\hline Case & 20 & $63.95 \pm 6.909$ & \multirow{2}{*}{$0.159 \mathrm{NS}$} \\
\hline Control & 40 & $66.79 \pm 7.396$ & \\
\hline Total & 60 & $65.83 \pm 7.302$ & \\
\hline
\end{tabular}

\section{Mean $\mathrm{FEV}_{1} / \mathrm{FVC}$ study population}

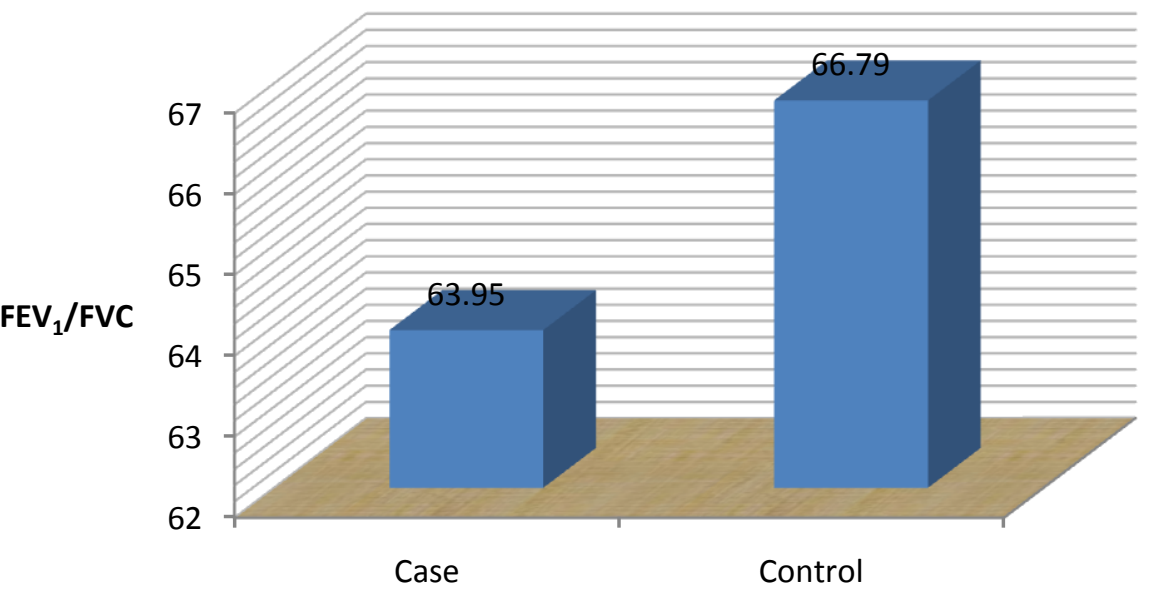

Table 17 shows percentage $\mathrm{FEV}_{1} / \mathrm{FVC}$ ratio in cases and controls. Although slight lower mean seen in cases $(63.95 \pm 6.909)$ as compared to controls $(66.79 \pm 7.396)$. No significant difference was observed according to mean $\mathrm{FEV}_{1} / \mathrm{FVC}$ in both the groups.

Table 18 Mean $\mathrm{FEV}_{1}$ (\% predicted) in study population

\begin{tabular}{|l|l|l|l|}
\hline FEV $_{1}(\%$ predicted $)$ & $\mathrm{n}$ & Mean & P Value LS \\
\hline Case & 20 & $52.53 \pm 13.381$ & \multirow{2}{*}{$0.001 \mathrm{HS}$} \\
\hline Control & 40 & $69.58 \pm 11.115$ & \\
\hline Total & 60 & $64.08 \pm 14.254$ & \\
\hline
\end{tabular}




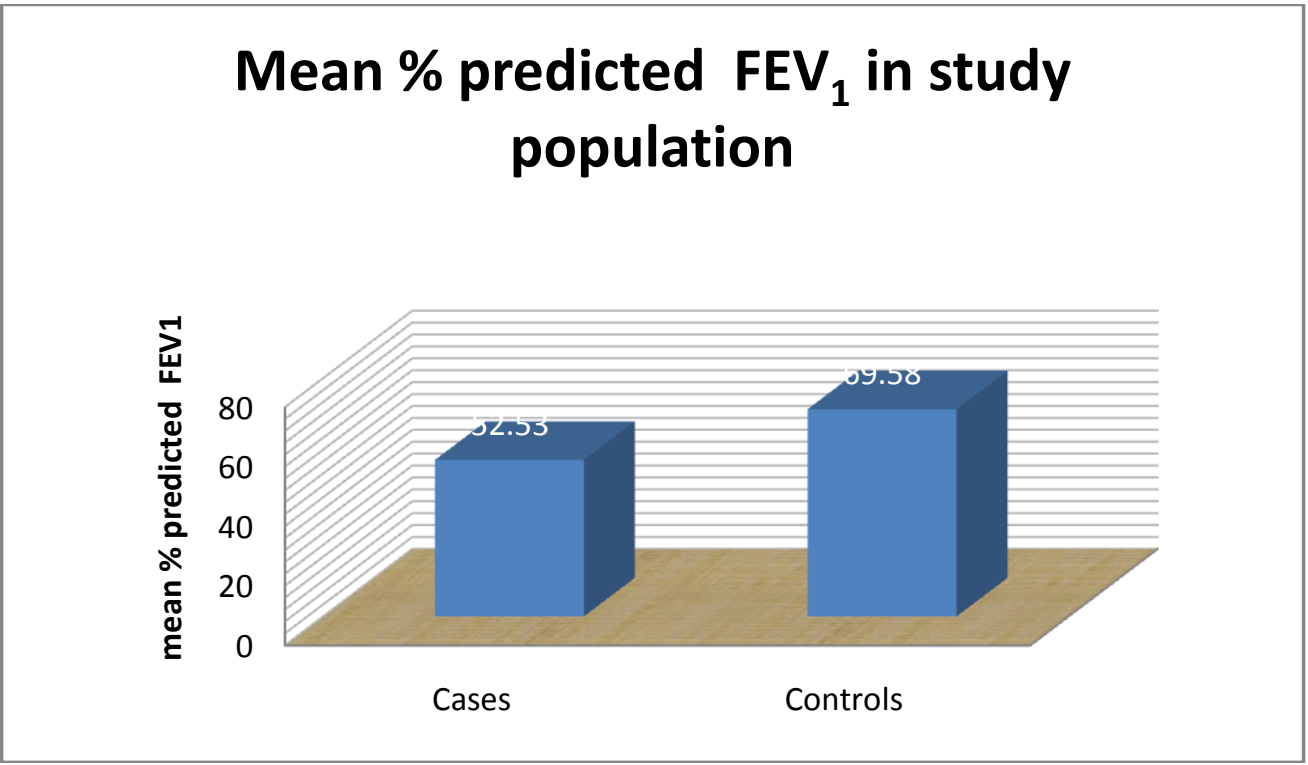

Table 18shows mean $\mathrm{FEV}_{1}$ (\% predicted) in cases and controls. Significantly lower mean $\mathrm{FEV}_{1}(\%$ predicted) (52.53 \pm 13.381$)$ was observed in case as compare to controls $(69.58 \pm 11.115)$.

Table 19 Chest $x$ ray findings

\begin{tabular}{|l|l|l|l|l|l|l|}
\hline \multirow{2}{*}{ Chest X Ray } & Total $(\mathrm{n}=60)$ & \multicolumn{2}{l|}{ Case $(\mathrm{n}=20)$} & \multicolumn{2}{l|}{ Control $(\mathrm{n}=40)$} & $\mathrm{P}$ Value \\
\cline { 2 - 7 } & & No & $\%$ & No. & $\%$ & \\
\hline Infiltration & 15 & 15 & 75 & 0 & 0 & $\mathrm{P}=0.000$ \\
\hline Cavity & 2 & 2 & 10 & 0 & 0 & $\mathrm{P}=0.204$ \\
\hline Old Healed Lesions & 33 & 3 & 15 & 30 & 75 & $\mathrm{P}=0.140$ \\
\hline B/L Hyperinflation & 10 & 0 & 0 & 10 & 25 & $\mathrm{P}=0.530$ \\
\hline
\end{tabular}

Chi Square Test

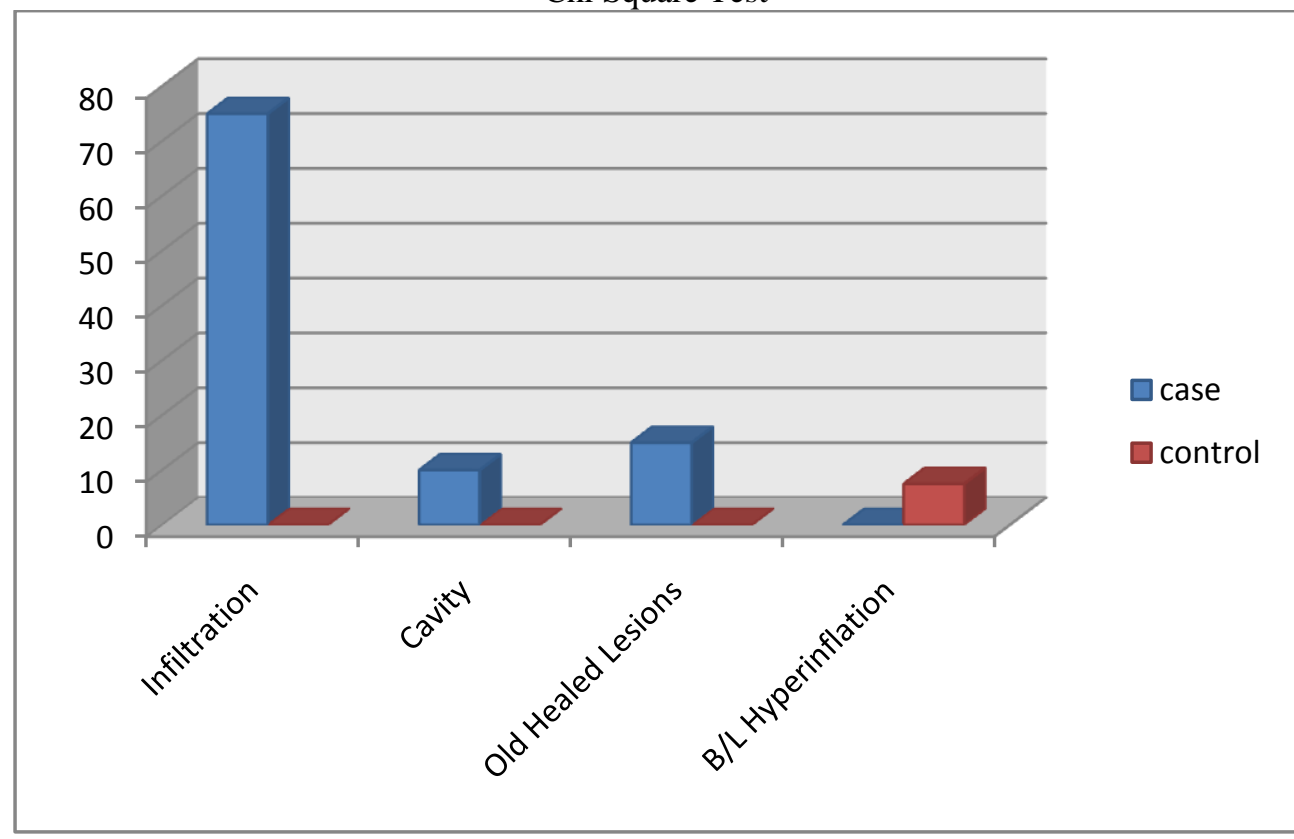

Table 19 show chest $\mathrm{x}$ ray findings in cases and controls. In chest $\mathrm{X}$ ray, Infiltration was most common findings , among cases,75\% patients had infiltrations followed by old healed lesion (15\%) and cavity $(10 \%)$ only infiltrations was significantly higher finding in cases as compared to controls.

Table 20 High resolution CT thorax finding in study population

\begin{tabular}{|l|l|l|l|l|}
\hline Findings & Total & Case $(\mathrm{n}=20)$ & Control $(\mathrm{n}=40)$ & P Value \\
\hline
\end{tabular}


“Study Of The Risk Factor, The Demographic Factor And Clinical Characteristi....

\begin{tabular}{|l|l|l|l|l|l|l|}
\hline & $(\mathrm{n}=60)$ & \multicolumn{3}{|l|}{} & & \\
\hline & & No & $\%$ & No. & $\%$ & \\
\hline Bronchiectasis & 14 & 9 & 45 & 5 & 12.5 & $\mathrm{P}=0.013$ \\
\hline Infiltrations & 20 & 16 & 80 & 4 & 10 & $\mathrm{P}=0.000$ \\
\hline Nodular & 20 & 16 & 80 & 4 & 10 & $\mathrm{P}=0.001$ \\
\hline Cavity & 3 & 2 & 10 & 1 & 2.5 & $\mathrm{P}=0.530$ \\
\hline
\end{tabular}

Chi Square Test

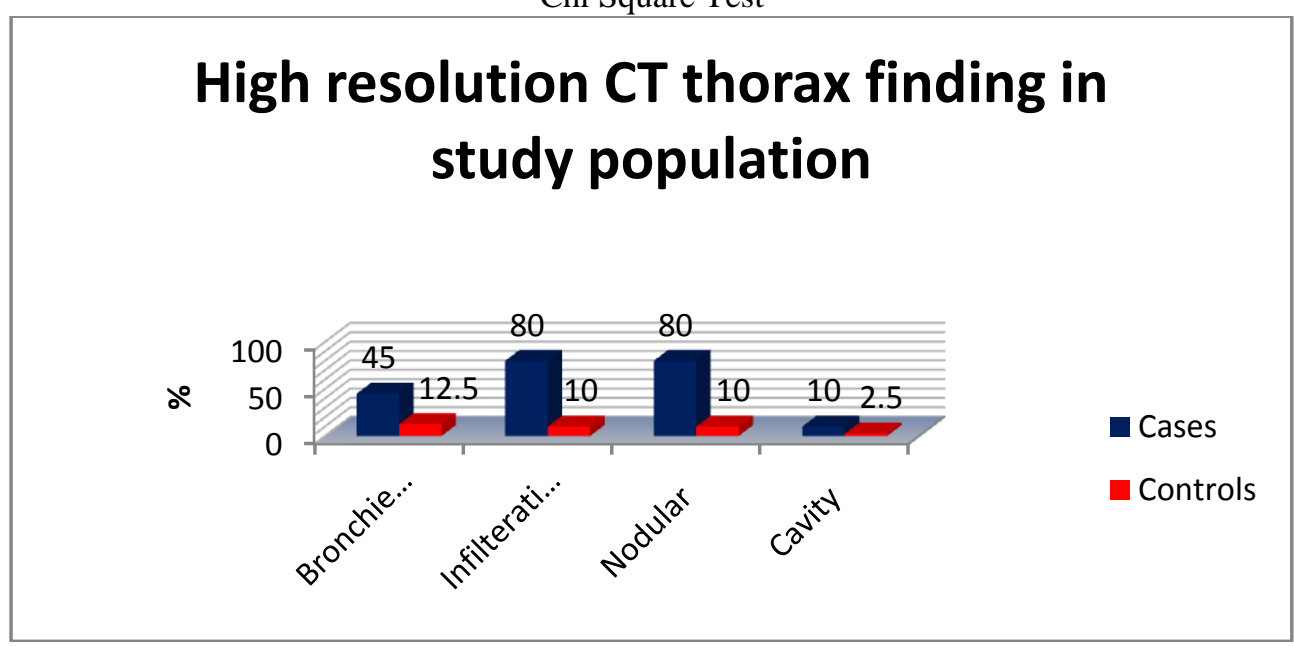

Table 20 shows HRCT finding in cases and controls. .In Chest CT scan abnormalities, predominant features were nodules and infiltration(80\% in each) followed by bronchiectasis (45\%) in all patients among the case group and all above three findings were significantly more in cases as compared to controls. $(\mathrm{P}<0.001 \mathrm{HS})$

Table 21 Distribution according to lobes involved

\begin{tabular}{|c|c|c|c|c|c|c|}
\hline & \multirow[t]{2}{*}{ Total $(n=60)$} & \multicolumn{2}{|c|}{ Case $(n=20)$} & \multicolumn{2}{|c|}{ Control $(n=40)$} & \multirow[t]{2}{*}{ P Value } \\
\hline & & No & $\%$ & No & $\%$ & \\
\hline Upper lobe & 13 & 8 & 40 & 5 & 12.5 & $\mathrm{P}=0.035$ \\
\hline Middle Lobe & 16 & 12 & 60 & 4 & 10 & $\mathrm{P}=0.000$ \\
\hline Lower Lobe & 11 & 6 & 30 & 5 & 12.5 & $\mathrm{P}=0.194$ \\
\hline Lingular Lobe & 3 & 2 & 10 & 1 & 2.5 & $\mathrm{P}=0.530$ \\
\hline
\end{tabular}

Chi Square Test

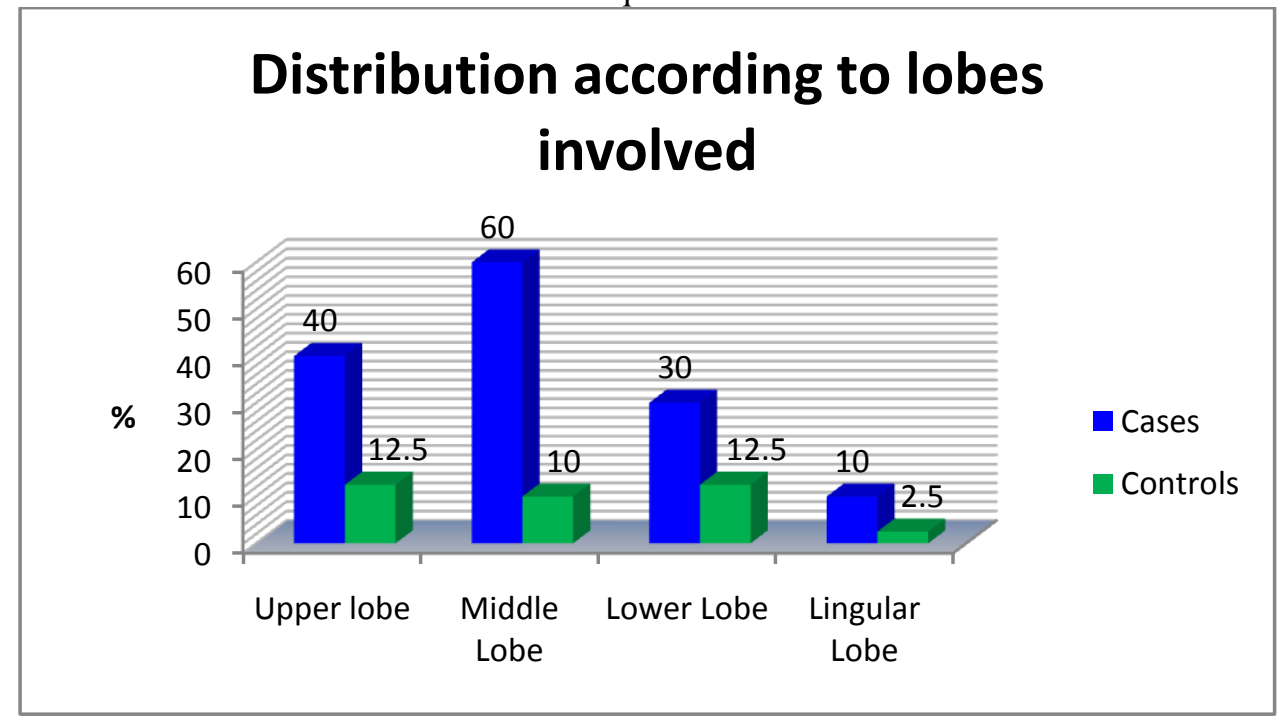

Table 21 shows distribution of lobe involved in cases and controls. Chest CT scan abnormalities predominated in the middle lobes in 16(26.7\%), upper in 13(21.7\%), in the lower lobes in $11(18.3 \%)$ and lingula in two $(5 \%)$ cases. Proportions of the cases were significantly more in upper lobes and middle lobe as compared to controls. 
Table-22 Distribution according to Mycobacterial species

\begin{tabular}{|l|l|l|}
\hline Mycobacteria Species & $\mathrm{n}=20$ & $\%$ \\
\hline M. Avium & 12 & 60 \\
\hline M.intracellulare & 4 & 20 \\
\hline M.kansasi & 2 & 10 \\
\hline M.xenopi & 2 & 10 \\
\hline Total & 20 & 100 \\
\hline
\end{tabular}

\section{Distribution according to Mycobacterial species}

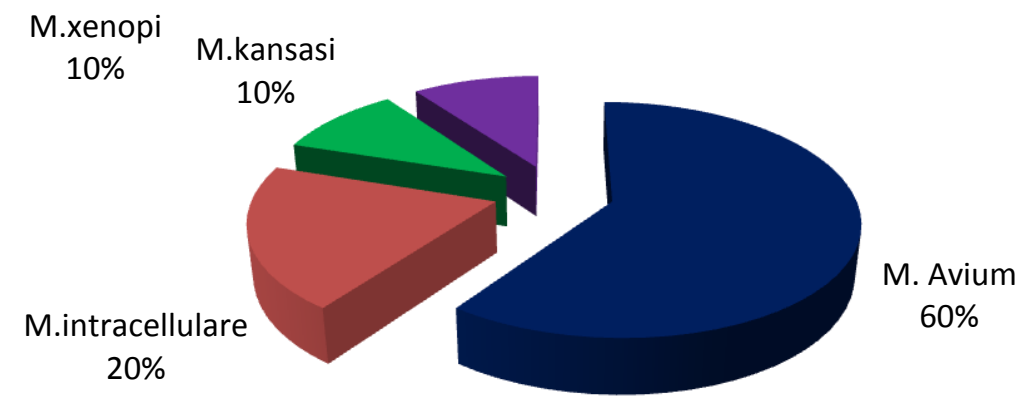

Table 22 shows distribution according to mycobacterial species. Twelve $(60 \%)$ patients were infected with Mycobacterium avium complex (MAC), and four (20\%) with Mycobacterium intracellulare and $10 \%$ each M. xenopi and Kansasi; no patient was infected with combination of any two speci

\section{Discussion}

Difficult-to-control asthma can be defined as that which is "inadequately or poorly controlled despite an appropriate therapeutic strategy that is adjusted to clinical severity ${ }^{19}$. The English-language literature tends to contain a variety of terms - including "refractory asthma", "difficult-to-control asthma, and difficult/therapyresistant asthma to define this most severe type. The prevalence of difficult-to-control asthma is not known with any degree of accuracy. In the literature, it is usually suggested to be around 5\% of all patients with asthma 22,23 , Symptomatic disease due to NTM is known to occur commonly in the presence of structural lung disease, such as COPD, bronchiectasis, cystic fibrosis, and pneumoconiosis. Structural changes in asthma like smooth muscle hypertrophy, thickening of basement membrane, mucus glands hypertrophy, edematous sub mucosa, and stratified non -ciliated structure with prominent goblet cells epithelium make asthma behave like a structural lung disease and may make it prone to NTM infection. ${ }^{24}$ Allergic bronchopulmonary aspergillosis (ABPA) is a known factor of any severity of asthma ,Most patients with ABPA are troubled by poorly controlled asthma ${ }^{25}$.

Although asthma is one of the common and wide spread chronic respiratory disease in the world, but NTM infection of the lungs have not been described in association with asthma, nor it is considered in the investigation of severe or difficult-to-control asthma.However bronchopulmonary fungal infection is a well known factor in difficult to control asthma ${ }^{26}$.In our study 60 patients were included in which 20 were case and 40 were control. Among case $14(70 \%)$ were female and $6(30 \%)$ were male while in control 18(45\%) were female and 22(55\%) were male. Most of the case had age more than 60 year. The mean age of case and control patients was $63.5 \pm 6.4$ years, and $44.6 \pm 9.131$ years respectively. Various study have shown that male sex is a risk factor for asthma in children prior to the age of 14, the prevalence of asthma is nearly twice as great in boys as in girls. As children get older the difference between the sex narrows, and by adulthood the prevalence of asthma is greater in women than in men. The reason for this sex difference is not clear. However lung size is smaller in males than in female at birth but larger in adulthood ${ }^{27}$ (GINA12), as in our study out of 60 subjects, 32 were female and 28 were male. Therefore in our study more subjects were female. In our study mean age of onset of asthma in case were 39.60 \pm 6.573 year while in control group mean age of onset were $35 \pm 6.228$ year. Mean age at onset of asthma were higher in cases than control which is significant. $(\mathrm{P}=0.028 \mathrm{~S})$, this can be explained by the fact that it adult onset asthma is non-atopic, more severe and associated with a faster decline in 
lung function ${ }^{28}$ so as case were more older than controls has more chance of NTM infection in case groups. Various studies show that asthma that starts in adulthood differs from the age at diagnosis determining the term adult -onset asthma varies from 12 years of age to 65 years of age. Dduration of asthma in case had significantly longer (23.70 \pm 7.787 year) as compared to control $(9.10 \pm 5.128$ year), in which found that more the duration of asthma more chance of NTM infection in difficult to control asthma ${ }^{29}$.In our study we found that the more number of Exacerbation/per year ,that frequent exacerbations lead to excess decline in function increase inflammatory process and pathology of airway remodeling leading to structural change in lung that can lead to more chance of NTM infection in difficult to control asthma who has frequent exacerbation. ${ }^{30}$ In our study no significant difference was observed according to type of inhaled corticosteroid were used ( $\mathrm{P}>0.05 \mathrm{NS}$ ). and concurrent pulmonary NTM disease. In our study mean duration of inhaled corticosteroid (ICS) in case were $15.05 \pm 4.915$ year and in control groups 5.00 \pm 3.457 . ICS use were observed for a significantly longer period of time in cases as compare to controls ( $\mathrm{P}<0.001 \mathrm{HS})$. use of oral steroid is more in case $12(60 \%)$ while in control group 3 patient $(7.5 \%)$ were significantly more used in cases as compared to control. $(\mathrm{P}<0.001 \mathrm{HS})$. There is good evidence supporting the effect of ICS on human pulmonary host defence, acting through several biological pathways, such as an inhibitory action on macrophage functions, a decrease in cytokine production and nitric oxide expression, which may lead to a failure to control infection. ${ }^{31}$ Various studies showed that, treatment with inhaled but also systemic corticosteroids may be an important risk factor for NTM infection. Use of ICS has been linked to an increased risk of pneumonia in patients with COPD ${ }^{32,33}$ and a similar phenomenon may be implicated in NTM infections among asthmatic patients. No significant difference was observed according to mean FEV1/FVC in both the groups, but significantly lower mean was observed to $\mathrm{FEV}_{1}$ in cases $(52.53 \pm 13.381)$ as compare to control $(69.58 \pm 11.115)$. Masayuki hojo etal were found that asthmatic patients with NTM infections had more severe airflow limitation than those without NTM infections ${ }^{34}$.The symptoms of NTM pulmonary disease are variable and nonspecific however Constitutional symptoms are progressively more prevalent with advancing NTM lung disease. .We found that the most common findings in chest $\mathrm{x}$ ray among cases, $75 \%$ patients had infiltrations followed by old healed lesion (15\%) and cavity (10\%) only infiltrations was significantly higher finding as compared to control and on chest CT scan abnormalities nodules and infiltration (80\% in each), bronchiectasis (45\%),predominated in the middle lobes in $16(26.7 \%)$ subjects, upper in $13(21.7 \%)$, in the lower lobes in eleven $(18.3 \%)$ and lingula in two (5\%).Proportion of the cases were significantly more in upper lobes and middle lobe as compared to control. Radiographic features of NTM lung disease is (similar to TB).Compared with the radiographic findings in TB and patients with NTM disease. Predominantly fibrocavitary radiographic changes tend to have the following characteristics: in NTM infection, (1)

Thin walled cavities with less surrounding parenchymal opacity, (2) Less bronchogenic but more contiguous spread of disease, and (3) Produce more marked involvement of pleura over the involved areas of the lungs. ${ }^{35}$ None of these differences, however, is sufficiently specific to exclude the diagnosis of TB on the basis of the radiographic appearance. Studies with HRCT of the chest have shown that up to $90 \%$ of patients with mid- and lower lung field noncavitary disease with MAC have associated multifocal bronchiectasis. In our study all the 60 subjects went through examination of sputum for AFB stain and Mycobacterial culture followed by species identification. Proportion of the cases $(11,55 \%)$ was significantly more positive for AFB sputum than the control. Proportion of the cases was significantly more positive for mycobacterium culture than the control. ( $\mathrm{P}<0.001 \mathrm{HS})$. Twelve $(60 \%)$ patients were infected with Mycobacteriumavium complex (MAC), and four (20\%) with Mycobacterium intrcellulare and 10\% each M. xenopi and Kansasi; no patient was infected with combination of any two species .Similar results were found in various studies.

\section{Summary}

A total 60 patients was taken in to the study with difficult to control asthma, Out of sixty, 20 were case and 40 were control, according to the non tuberculous mycobacterial culture of sputum. Cases were significantly older than the controls. Cases had significantly longer disease mean duration of asthma as compared to control. Significantly more exacerbation/year was found among cases as compare to controls and cases had taken inhaled corticosteroids for a significantly longer period of time as compare to controls. In CT Chest Proportions of the cases having upper lobes and middle lobe diseases were significantly higher in case as compared to controls. Twelve (60\%) patients were infected with Mycobacterium avium complex (MAC), and four (20\%) with Mycobacterium intracellulare and $10 \%$ each M. xenopi and Kansasi; no patient was infected with combination of any two species.

\section{Conclusion}

In difficult to control asthma patients provide evidence that NTM infection can be associated with asthma and should be considered in difficult to- treat disease, especially in older individuals, late onset asthma 
longer duration of asthma, frequent exacerbation and past hospitalization, more severe airflow obstruction greater exposure to inhaled or systemic corticosteroids.

\section{Bibilography}

[1]. Gloabal initiative of asthma .Global strategy for asthma management and prevention revised 2014.

[2]. Auerbach I, Springer C, Godfrey S. Total population survey of the frequency and severity of asthma in 17 year old boys in an urban area in Israel. Thorax 1993;48:139-141.

[3]. American Thoracic Society. Proceedings of the ATS Workshop on Refractory Asthma. Current understanding, recommendations, and unanswered questions. Am J Respir Crit Care Med. 2000; 162:2341-51.

[4]. Gencay M , Rüdiger JJ , Tamm M , Solér M , Perruchoud AP, Roth M . Increased frequency of Chlamydia pneumonia antibodies in patients with asthma. Am J Respir Crit Care Med . $2001 ; 163$ ( 5 ): 1097 - 1100 .

[5]. Sutherland ER, Martin RJ . Asthma and atypical bacterial infection . Chest . 2007 ; 132 ( 6 ): 1962 - 1966

[6]. Von Reyn CF, Waddell RD, Eaton T, Arbeit RD, Maslow JN, Barber TW, Brindle RJ, Gilks CF, Lumio J, Lahdevirta J. Et al. Isolation of Mycobacterium avium complex from water in the United States, Finland, Zaire, and Kenya. J Clin Microbiol 1993;1:3227-3230.

[7]. Meissner G, Anz W. Sources of Mycobacterium avium-complex infection resulting in human disease. Am Rev Respir Dis 1977;116:1057-1064.

[8]. Olivier KN, Weber DJ, Wallace RJ Jr, Faiz AR, Lee JH, Zhang Y, Brown-Elliot BA, Handler A, Wilson RW, Schechter MS, et al.; Nontuberculous Mycobacteria in Cystic Fibrosis Study Group. Nontuberculous mycobacteria. I: multicenter prevalence study in cystic Fibrosis. Am J Respir Crit Care Med 2003;167:828-834.

[9]. Marras TK, Chedore P, Ying AM, Jamieson F . Isolation prevalence of pulmonary non-tuberculous mycobacteria in Ontario, 19972003. Thorax . $2007 ; 62$ ( 8 ): $661-666$.

[10]. Denning etal, The link between fungi and severe asthma a summary of the evidence : Eur Respir J 2006; 27 : $615-626$.

[11]. Schwartz HJ, Greenberger PA. The prevalence of allergic bronchopulmonary aspergillosis in patients with asthma, determined by serologic and radiologic criteria in patients at risk. J Lab Clin Med 1991; 117: 138-142

[12]. Smith N , Denning DW . Underlying pulmonary disease frequency in patients with chronic pulmonary aspergillosis . Eur Respir J $2011 ; 37: 865-872$.

[13]. Agarwal R , Aggarwal AN , Gupta D , Jindal SK . A spergillus hypersensitivity and allergic bronchopulmonary aspergillosis in patients with bronchial asthma: systematic review and meta-analysis . Int J Tuberc Lung Dis 2009; $13: 936$ - 944

[14]. Chanez P ,Wenzel SE, Anderson GP , et al . Severe asthma in adults: what are the important questions? J Allergy Clin Immunol . $2007 ; 119$ (6): 1337 - 1348

[15]. Schwartz HJ, Greenberger PA. The prevalence of allergic bronchopulmonary aspergillosis in patients with asthma, determined by serologic and radiologic criteria in patients at risk. J Lab Clin Med 1991; 117: 138-142

[16]. Fritscher, Nontuberculous Mycobacterial Infection as a Cause of Diffi cult-to-Control Asthma CHEST 1391 JANUARY, 2011.

[17]. Use of the genotype Mycobacterium CM and AS Assays To Analyze 76 Nontuberculous Mycobacterial Isolates from Greece J Clin Microbiol. 2006 June; 44(6): 2244-2246.

[18]. Anderson C, Inhaber N, Menzies D. Comparison of sputum induction with fiber-optic bronchoscopy in the diagnosis of tuberculosis. Am J Respir Crit Care Med 1995;152:1570-1574.

[19]. Elsasser S. Perruchoud AP. Pathophysiology of bronchial asthma. 1992; 81(45):1346-9.

[20]. National Institutes of Health, National Heart Lung and Blood Institute Workshop report, 2002. Global strategy for asthma management and prevention. NIH publication No. 02-3659.

[21]. Chan MTS, Leung DYM, Szefler SJ, Spahn JD. Difficult-to-control asthma: clinical characteristics of steroid-insensitive asthma. J Allergy Clin Immun 1998;101:594-601.

[22]. Panhuysen CIM, Vonk JM, Koeter GH, Schouten JP, Van Altena R, Bleecker ER, Postma DS. Adult patients may outgrow their asthma. A 25-year followup study. Am J Respir Crit Care Med 1997;155:1267-1272.

[23]. Roorda RJ, Gerritsen J, Van Aalderen WMC, Schouten JP, Veltman JC, Weiss ST, Knol K. Followup of asthma from childhood to adulthood: influence of potential childhood risk factors on the outcome of pulmonary function and bronchial responsiveness in adulthood. J Allergy Clin Immunol 1994;93:575-584.

[24]. Larsen GL, Cherniack RM, Irvin CG. Pulmonary physiology of severe asthma in children and adults. In: Szefler SJ, Leung DYM, editors. Severe asthma: pathogenesis and clinical management. New York: Marcel Dekker; 1996.

[25]. Chetta A, Foresi A, Donno MD, Bertorelli G, Pesci A, Olivieri D. Airway remodeling is a distinctive feature of asthma and is related to severity of asthma. Chest 1997;111:852-857.

[26]. Fish JE, Peters SP. Airway remodeling and persistent airway obstruction is asthma. J Allergy Clin Immunol 1999;104:509-516.

[27]. Peat JK, Woolcock AJ, Collen K. Rate of decline of lung function in subjects with asthma. Eur J Respir Dis 1987;70:171-179.

[28]. Agertoft L, Pedersen S. Effects of long-term treatment with an inhaled corticosteroid on growth and pulmonary function in asthmatic children. Respir Med 1994;88:373-381.

[29]. Postma DS, Bleecker ER, Amelung PJ, Holroyd KJ, Xu J, Panhuysen CIMA, Levitt RC. Genetic susceptibility to asthmabronchial hyperresponsiveness coinherited with a major gene for atopy. N Engl J Med 1995;333:894-900.

[30]. Kaminskyda, Wenzel SE, Carcano $\mathrm{C}$ and colleagues Hyperpnea-induced changes in parenchymal lung mechanics in normal subjects and in asthmatics. Am J Respir Crit Care Med 1997;155:1260-1266.

[31]. Calverley PM , Anderson JA , Celli B , et al ; TORCH investigators . Salmeterol and fl uticasone propionate and survival in chronic obstructive pulmonary disease. N Engl J Med . 2007 ; 356 ( 8 ): 775 - 789.

[32]. Holgate ST . Epithelium dysfunction in asthma . J Allergy Clin Immunol . 2007 ; 120 ( 6 ): 1233 - 1244.

[33]. Middleton AM , Chadwick MV, Nicholson AG, et al. Inhibition of adherence of Mycobacterium avium complex and Mycobacterium tuberculosis to fi bronectin on the respiratory mucosa . Respir Med . 2004 ; 98 ( 12 ): 1203 - 1206

[34]. Hojo M, Increased risk of nontuberculous mycobacterial infection in asthmatic patients using long-term inhaled corticosteroid therapy Respirology (2012) 17, 185-190

[35]. Selma B. De Nijs, Lisette N. Venekamp and Elisabeth H. Bel Adult-onset asthma: is it really different?Eur Respir Rev 2013; 22: $127,44-52$. 